\title{
Scientific Investigation of Works of Art
}

$\mathrm{I}^{\mathrm{N}}$ the field of the fine arts, it is axiomatic that the history of style cannot be separated from the history of technique: and critical study of the latter depends upon two sources of information. Of these, documentary evidence is the more obvious and the less readily accessible. Some such manuscripts are of classical importance, and have been frequently edited and translated: probably the best known are the fifteenth century "Libro dell' Arte" of Cennino Cennini, and the much earlier "Schedula Diversarum Artium" of Theophilus Presbyter, of which first-class translations, critically edited and most copiously annotated, have recently been published. Numerous other early and medieval texts dealing with all phases of contemporary craftsmanship have been intensively studied, such as the Lucca "Compositiones" and the fourteenth century "De Arte Illuminandi", while many unpublished sources have yet to receive due attention. But comparatively few craftsmen have thus placed on written record their workshop methods: and it can therefore scarcely be too strongly emphasised that detailed analytical study of actual surviving works of art constitutes a second potential source of information of the very highest importance.

Obviously, such sources are much more frequent than purely documentary evidence on the history of medieval craftsmanship: and the technique whereby a specific work of art was fashioned, be it painting, bronze, pottery or textile, may often be detected by the trained and discerning eye. It cannot be done in a day. Many tricks of medieval craftsmanship are still stubborn secrets: and though scientific methods of investigation, applied with reserve and artistic appreciation, have of recent years unravelled a good many such problems, yet the unwritten secret of, for example, the brothers Van Eyck, still continues to be 'discovered' at fairly regular intervals.

The names of a good many pioneer workers are intimately associated with this intensely interesting field where science and the fine arts overlap. It is perhaps invidious to particularise : but Prof. Eibner and his collaborators at Munich, and Prof. A. P. Laurie in Great Britain, among many other workers, have contributed classical researches to the corpus of available knowledge. It should not be forgotten, further, that many museums, galleries, private research workers, and picture-restorers such as Dr. de Wild, have all made use of scientific methods for the examination of works of art. But all have admitted the disadvantages inherent in the general absence of a co-ordinating centre of research, though of recent years this deficiency has to some extent been remedied by the excellent work of one or two research departments. The laboratory of the Fogg Art Museum, at Harvard University, for example, has systematised many lines of research, and has provided by its quarterly publication, Technical Studies in the Field of the Fine Arts, a journal devoted exclusively to dis. seminating knowledge in this field. Further, the invaluable work carried out at the Research Laboratory of the British Museum has led to excellent publications on the constitution and care of museum pieces and works of art of various kinds. While paintings have, generally speaking, received little treatment at this latter centre, systematic investigation of such problems, particularly as applied to Russian icons and Byzantine wallpaintings, has been carried out in Moscow at the Institute of Archæological Technology and the Restoration Workshop. The results achieved there are not so widely known as they should be, however, largely owing to the language difficulty.

The recent establishment, by the University of London, of a Scientific Department at the Courtauld Institute of Art, has focused attention upon this field once more. The urgent need for the foundation of a centre where systematic investigation could be carried out into the physical character of works of art, and into the problems connected with their conservation and restoration, was made very clear at a Conference on Ailing Pictures convened by the Department of Scientific and Industrial Research on October 20, 1931. Full tribute was there paid to the work of the British Museum Research Laboratory, and of private investigators : but it was felt that an independent and preferably academic centre would have great advantages over any existing institution, not only in carrying out research, but also in co-ordinating work already being conducted elsewhere. The new laboratory marks the fulfilment of the views expressed at this meeting: it is now fully equipped, and work is in progress. In addition to its research and educational activities, the laboratory is prepared to make scientific investigation into works of art of any type submitted by their owners, both public and private, reporting on their physical constitution and condition, and advising on questions of conservation and restoration.

Reports are, however, limited very strictly to matters of scientifically ascertainable fact: questions of attribution to a particular master are not taken up. The technique of a Holbein or a Rembrandt cannot yet be expressed as a mathematical function of the materials employed, nor can the impasto of a Rubens at present be differentiated 
from that of his pupils by any quality or quantity accurately measurable in absolute units.

It is significant of the recent increased interest in such problems in Great Britain that the National Gallery has installed specialised equipment for the physical investigation and characterisation of its pictures : and this almost simultaneous establishment of two such research departments in London can scarcely fail to have an important bearing on this field of investigation.

The results previously obtained have, perhaps inevitably, given rise to a certain amount of sensational publicity in the Press. This is very regrettable: for not only has it led to popular misconceptions, and to the making of extravagant claims for certain scientific weapons, but also it has tended to suggest that all manner of questions, including the thorny problem of attribution, can be settled rapidly and with certainty by scientific means. The publicity accorded to the occasional detection of art forgeries by examination with $\mathrm{X}$-rays, and with ultra-violet and infra-red radiation, has led many a layman to believe that such methods invariably reveal hidden features of deep significance. In actual practice, nine out of every ten paintings, on $\mathrm{X}$-ray examination, show nothing of significance-or, at least, nothing which can with certainty be interpreted at the present stage of our experience. The outstanding difficulty in investigations of this kind is that of establishing a satisfactory control experiment-a norm for comparison. It should never be forgotten that a work of art, of practically any kind, has to be regarded as a 'living' system, in a state of physico-chemical equilibrium which can be radically altered by factors at present almost unknown-as witness the sudden disintegration of certain Italian frescoes, without warning, after centuries of healthy 'life'. The independent variables controlling such a system are so numerous that it is doubtful whether any given work of art will ever be defined by a set of specific and reproducible conditions. Its very nature is so intensely individual that the cleverest forgery in existence would be an unsatisfactory control for experiment on the original. To generalise on a few striking cases is, if possible, even less permissible here than in the exact sciences : and significant progress will be obtained only after long-continued experiment under carefully controlled conditions.

P. D. R,

\section{Origin of the British Flora}

IKE all other biological phenomena, the L British flora is determined by two classes of factors, those of history and constitution on one hand, and those of environment on the other. It is obvious that only those species which can at least tolerate the climate of these islands can continue to live here: the discussion held at the Royal Society on March 28 was concerned mainly with the problem of how and when they came. Light was thrown on this subject by contributions not only from taxonomists and students of the geographical distribution of species, but also from ecologists, meteorologists, geologists and archæologists, though it cannot be said that the problem taken as a whole is very close to solution despite the intensified field-work of recent years. We are in fact no farther than the beginning of the laborious collection and analysis of detailed facts which alone can eventually lead to general agreement.

Mrs. E. M. Reid opened with a paper on "British Floras antecedent to the Great Ice Age". In dealing with the Tertiary floras, she showed that that of the London clay has a large preponderance of tropical, mostly Indo-Malayan forms, which she explained by supposing migration to north-western Europe along the shores of the Tethys Sea-that greatly extended 'Mediterranean' which persisted through so many geological ages. The evidence is that some existing British genera, absent from the London Clay, existed in these regions in earlier times (before the London Clay was laid down) and were presumably driven out by this invasion of tropical climate and flora from the south-east, but the floras of later deposits (subsequent to the London Clay) show a steadily increasing percentage of living British genera, culminating in the late Pliocene with 97 per cent. It is generally accepted that the climate and flora of the Cromer Forest bed at the top of the Pliocene were roughly equivalent to those of to-day, and may therefore be taken as the real starting point of the modern flora.

Then came the cold of the Pleistocene with the advance of the great continental ice-sheet from Scandinavia and the formation of glacial systems in the mountains of Great Britain. It is obvious that these conditions must have exterminated or driven southward most of the existing flora, since the ice advanced at one time to the northern edge of the Thames Valley, and later to South Wales. It is now established, however, that there were four successive glaciations in England-though these do not necessarily correspond at all closely with those of the Continent--and correspondingly three interglacial phases. Prof. P. G. H. Boswell, whose work has greatly increased our knowledge of the Pleistocene period in Britain, sketched the 